\title{
Tumor matrix remodeling and novel immunotherapies: the promise of matrix- derived immune biomarkers
}

\author{
Muhammad Umair Mushtaq ${ }^{1,2}$, Athanasios Papadas ${ }^{1,2}$, Adam Pagenkopf $^{1,2}$, Evan Flietner ${ }^{1,2}$, Zachary Morrow ${ }^{1,2}$, \\ Sibgha Gull Chaudhary ${ }^{1,2}$ and Fotis Asimakopoulos ${ }^{1,2^{*}}$ (D)
}

\begin{abstract}
Recent advances in our understanding of the dynamics of cellular cross-talk have highlighted the significance of host-versus-tumor effect that can be harnessed with immune therapies. Tumors exploit immune checkpoints to evade adaptive immune responses. Cancer immunotherapy has witnessed a revolution in the past decade with the development of immune checkpoint inhibitors (ICls), monoclonal antibodies against cytotoxic T lymphocyte antigen 4 (CTLA-4) and programmed cell death protein 1 (PD-1) or their ligands, such as PD1 ligand 1 (PD-L1). ICls have been reported to have activity against a broad range of tumor types, in both solid organ and hematologic malignancy contexts. However, less than one-third of the patients achieve a durable and meaningful treatment response. Expression of immune checkpoint ligands (e.g., PD-L1), mutational burden and tumor-infiltrating lymphocytes are currently used as biomarkers for predicting response to ICls. However, they do not reliably predict which patients will benefit from these therapies. There is dire need to discover novel biomarkers to predict treatment efficacy and to identify areas for development of combination strategies to improve response rates. Emerging evidence suggests key roles of tumor extracellular matrix (ECM) components and their proteolytic remodeling products in regulating each step of the cancer-immunity cycle. Here we review tumor matrix dynamics and matrix remodeling in context of anti-tumor immune responses and immunotherapy and propose the exploration of matrix-based biomarkers to identify candidates for immune therapy.
\end{abstract}

Keywords: Adaptive immune response, Immune checkpoint inhibitors, Immunotherapy, Tumor microenvironment, Matrix remodeling, Immune biomarkers

\section{Background}

The adaptive immune response protects against foreign threats, including infections and tumors. The therapeutic potential of host-versus-tumor effect can be harnessed with novel immune therapies. $\mathrm{CD} 4^{+}$and $\mathrm{CD} 8^{+} \mathrm{T}$ lymphocytes comprise primary effector cells against tumors. Initial antigen-mediated activation of $\mathrm{T}$ cells is modulated by several regulatory mechanisms, including engagement co-stimulatory signals like the binding of CD28 on T cells to CD80/B7-1 and/or CD86/B7-2 on antigen-presenting cells. Immune checkpoint pathways that have evolved as a

\footnotetext{
* Correspondence: fasimako@medicine.wisc.edu

${ }^{1}$ Department of Medicine, University of Wisconsin School of Medicine and Public Health, Madison, WI, USA

University of Wisconsin Carbone Cancer Center, 1111 Highland Avenue, WIMR 4031, Madison, WI 53705, USA
}

mechanism to avoid auto-immunity, can be targeted with immune checkpoint inhibitors (ICIs). Immune checkpoints are inhibitory regulators that act as "breaks" on the immune response. Cytotoxic $\mathrm{T}$ lymphocyte antigen 4 (CTLA-4; CD152) competes with CD28 for the ligands CD80 and CD86, and antagonizes T cell receptor (TCR) signaling [1-3]. Programmed cell death protein 1 (PD-1; CD279) counters positive signaling by the TCR by engaging its ligands programmed cell death 1 ligand 1 (PD-L1; CD274/B7-H1), and/or PD-L2 (CD273/B7-DC) [4-7]. The generation of an inflammatory milieu in the tumor microenvironment (TME) and infiltration of activated lymphocytes induce tumor escape mechanisms that exploit immune checkpoints to evade adaptive immune responses, including up-regulation of PD-L1 in TME and CTLA-4 in peripheral lymphoid tissues [8-10]. 
Immune checkpoint inhibitors: urgent need for predictive biomarkers

Tumor immunotherapy has witnessed a revolution in the past decade. The clinical successes of ICIs, monoclonal antibodies (mAb) against CTLA-4 and PD-1 pathways, was a breakthrough achievement. In 2010, a randomized phase III trial reported remarkable response to Ipilimumab, mAb against CTLA-4, in melanoma patients [11]. Ipilimumab was the first checkpoint inhibitor to be approved by the Food and Drug Administration (FDA). Pembrolizumab and nivolumab, mAbs against PD-1, were FDA-approved in 2014. Atezolizumab, mAb against PD-L1, was FDA-approved in 2016. Two mAbs to PD-L1, Durvalumab and Avelumab, were granted breakthrough FDA approval in 2017 after promising results in non-small cell lung cancer (NSCLC), urothelial carcinoma and Merkel cell carcinoma [12-14].

Despite the rapid progress of approvals for these classes of agents, the accumulated experience demonstrated that overall, only one-third of the patients achieve a durable and meaningful response. With CTLA-4 blockade by Ipilimumab or PD-1 inhibition with Nivolumab, response rates of $30-40 \%$ were observed in melanoma patients as monotherapies and combination therapy achieved a response rate of over 50\% [15-18]. In NSCLC, a response rate of about $20 \%$ is observed with Nivolumab, Pembrolizumab and Atezolizumab [19-22]. Response rates of 13\% (head and neck squamous cell cancer), 25\%-40\% (renal cell cancer), and 31\% (microsatellite-unstable colon cancers) have been reported with PD-1 blockade [23-25]. In relapsed/refractory Hodgkin's lymphoma, a complete response rate of $17 \%$ and partial response rate of $70 \%$ has been reported with Nivolumab [26]. A complete remission rate of $22 \%$ is noted in relapsed/refractory acute myeloid leukemia with Nivolumab combined with a hypomethylating agent [27]. There are several on-going bench and clinical trials for ICIs across all tumor types. However, it is clear that to-date, the majority of patients do not benefit from checkpoint inhibition immunotherapy. There is dire need to explore biomarkers to predict response to treatment and to identify areas for development of combination agents to improve response rates and mitigate toxicities.

\section{Predictors of response to immune checkpoint inhibitors: current limitations}

Expression of immune checkpoints: challenges and pitfalls High expression of PD-L1 is regarded as a marker of an active anti-tumor immune response and correlates with adaptive immune resistance in several tumor types, including melanoma, NSCLC, Merkel cell carcinoma, breast cancer, mismatch-repair deficient tumors, and Hodgkin's lymphoma [10, 19, 21, 22, 26, 28-34]. However, expression of PD-L1 does not reliably predict response to ICI $[18,35,36]$. In NSCLC, no association of PD-L1 expression with response has been reported with Nivolumab [20]; however, high PD-L1 expression in NSCLC almost doubled the response rate to Pembrolizumab to about $45 \%$ from 19\% [37]. In melanoma, tumor tissue PD-L1 expression showed significant correlation with response in five out of eight PD-1 ICI studies but did not predict response to CTLA-4 ICI therapy [38]. Notably, there are several limitations concerning PD-L1 expression assays, including membranous versus cytoplasmic expression, expression by multiple cell types in the TME, focal expression in tumor samples, changes in expression over the course of disease progression and with radiation and epigenetic chemotherapy, as well as variability in laboratory techniques and antibodies used in the assay [35].

Discordance between PD-L1 expression in metastatic sites and primary tumors has been noted in bladder cancer patients, suggesting the dynamic nature of TME [39]. In contrast to pre-treatment biopsies, tumor biopsies in early treatment phase in metastatic melanoma patients treated with sequential CTLA-4 and PD-1 blockade showed high expression of PD-1 and PD-L1 in responders [40]. In NSCLC cells, PD-L1 genomic locus amplification correlated with expression of PD-L1 and antitumor benefit [41]. CTLA-4 and PD-L2 genes were expressed at higher levels in the pretreatment melanoma tumors of patients who derived benefit from CTLA-4 antibodies [42]. However, PD-L1, PD-L2 and CTLA-4 did not demonstrate higher expression in anti-PD-1-responsive melanoma patients [43].

\section{Somatic mutations and neoantigen load}

A systemic review of melanoma patients showed that responses to ICIs correlated with mutational load, neoantigen load, and immune-related gene expression [38]. High mutational burden and neo-epitope density have been noted in responding tumors; however, there is significant overlap with non-responding tumors [34, 42, 44]. Colon cancers with microsatellite instability (MSI) have large mutational burdens and higher response rates to PD-1 blockade [23, 33]. However, high mutational burdens do not always predict responders to ICI therapy, primarily because of an extremely diverse array of resultant somatic mutations [34, 42-44]. Neoantigen heterogeneity influences immune surveillance. Clonal neoantigens have been reported to induce immune reactivity and sensitivity to immune checkpoint blockade [45].

\section{Immune profiling signatures}

Genetic and immune heterogeneity has been observed in melanoma tumors responding to immunotherapy [46]: individual gene-based expression analysis has revealed that mesenchymal and $\mathrm{T}$ cell-suppressive inflammatory or angiogenic tumor phenotypes are associated with 
innate anti-PD-1 resistance [43]. Genes expressed higher in non-responding pre-treatment tumors included mesenchymal transition genes, immunosuppressive genes, and monocyte and macrophage chemotactic genes [43].

\section{Tumor-infiltrating cytotoxic lymphocytes (CTL)}

The success of checkpoint blockade depends on prior recruitment of tumor-infiltrating lymphocytes, particularly $\mathrm{CD}^{+}$cytotoxic T- lymphocytes (CTL), in the TME. These CTL are located at the invasive tumor margin and intratumorally, and are negatively regulated by PD-1/ PD-L1-mediated adaptive immune resistance. In metastatic melanoma, the detection of CTL at the tumor margin predicted better response to ICI [10, 38, 40, 47]. Colon cancers with MSI are highly infiltrated with T cells relative to microsatellite-stable (MSS) colon cancers, particularly with CTL [48]. Chemokines of CCL and CXCL family have been associated with CTL recruitment to melanoma metastases [49]. Higher levels of CCL2, CXCL4 and CXCL12 have been noted in responding tumors [47]. Clonal $\mathrm{T}$ cell responses have been associated with ICI clinical responses [10, 50-52]. It remains unclear how ICIs affect $\mathrm{CD}^{+}$effector memory cells that might explain durable response observed in many patients [53]. Conversely, brisk CTL infiltrates at time of progression in patients on immune checkpoint blockade has also been noted, suggesting that effector immune cells are impaired by the TME leading to therapeutic resistance [54].

\section{Tumor-infiltrating regulatory $T$ cells (Tregs)}

Tumor-infiltrating Tregs, in particular, $\mathrm{CD}^{+}{ }^{+} \mathrm{T}$ cells expressing interleukin-2 receptor chair-alpha (IL2R $\alpha$; CD25) and transcription factor forkhead-box P3 (FOXP3), suppress CTL and contribute to a tumorigenic TME. They promote tumor growth by diverse mechanisms, including expression of immune checkpoints (CTLA-4, PD-1 and others) as well as production of IL10 and transforming growth factor-beta (TGF- $\beta$ ) $[55,56]$. CTLA-4 blockade expands the population of Tregs and high levels of soluble CD25 (IL2R $\alpha$ ) has been correlated with resistance to anti-CTLA-4 therapy [57]. PD-1 blockade with Nivolumab promoted CTL proliferation and resistance to Treg-mediated suppression, by down-regulating intracellular expression of FOXP3 [58]. An increased ratio of CTL compared with Treg in tumor tissue has been associated with response to CTLA-4 and PD-1 blockade $[27,59]$.

\section{Tumor-infiltrating regulatory myeloid cells}

Tumor-infiltrating myeloid cells, including myeloid-derived-suppressor cells (MDSCs), tumor-associated granulocytes, tumor-associated macrophages (TAMs) and dendritic cells (DCs), generate and promote both immunogenic and tolerogenic responses [60-63]. MDSCs are immune-suppressive immature myeloid cells that support tumor growth and predict poor prognosis [64-67]. MDSCs exert their effects by various mechanisms including arginine 1 expression [68], nitric oxide [69], cyclooxygenase 2 [70], reactive oxygen species [71], and Treg activation via CD40-CD40L interactions [72]. In melanoma, an elevated level of CXCL17, which recruits MDSCs, predicts non-responders to ICI $[47,73]$.

Tumor-associated neutrophils (TANs) and TAMs have been classified to have an anti-tumor (type 1) or protumor (type 2) phenotype [74-77]. Pro-tumor effects of TANs include dampening of CTL response, increased angiogenesis, and modulation of cellular trafficking [78]. Type 1 TAMs (M1) produce immune-stimulatory cytokines, like IL6, IL12 and CXCL9, that promote infiltration of CTLs whereas type 2 TAMs (M2) support tumor growth by diverse pathways, including production of angiogenic factors like IL-10 and CCL22, matrix remodeling by proteases, and inhibition of CTLs and DCs [79]. PD-L1 expression by monocytes and TAMs promote immune evasion and correlate with disease progression in hepatocellular carcinoma [80]. Fc-gamma receptors (FcyRs) expressed by M2 TAMs facilitate anti-tumor response to CTLA-4 inhibition through Treg depletion $[81,82]$. Tumor-infiltrating eosinophils promote infiltration of CTLs, by varied machnisms, including polarization of TAMs and normalization of tumor vasculature, and predict a better prognosis in colon cancer [83, 84]. Tumor-infiltrating mast cells recruit MDSCs and upregulate production of pro-inflammatory cytokines resulting in Treg infiltration and immune suppression [85-87].

DCs, including classical (cDCs) and plasmacytoid DCs (pDCs), are antigen-presenting cells that prime and regulate CTL responses. Anti-viral immune responses rely heavily on pDC-derived type I interferons (IFN) [88]; however in tumors pDCs often play potent immunosuppressive roles [89]. Tumor-infiltrating $\mathrm{CDC}$ increase $\mathrm{T}$ cell activation in lung cancer and melanoma patients, forming tertiary lymphoid clusters, and are associated with better outcomes [90-92]. Tertiary lymphoid clusters correlated with improved survival in pancreatic cancer [93]. CD103 (integrin $\alpha \mathrm{E})^{+} \mathrm{cDCs}$ (Batf3-cDC, cDC1) are associated with CTL activation and increased overall survival for patients with breast, head and neck or lung cancer [94]. $\beta$-catenin signaling prevents tumor infiltration by DC and CTLs and imparts resistance to ICIs in melanoma [95]. In lung adenocarcinoma murine models, immunogenic chemotherapy (oxaliplatin-cyclophosphamide) has been reported to up-regulate toll-like receptor 4 (TLR-4) on tumor-infiltrating Batf3-cDCs, which leads to recruitment of CTLs and sensitization to ICIs [96].

\section{Gut microbiota}

Emerging evidence has suggested that the cross-talk between gut microbiota and immune cells plays a role in 
determining responses to ICI therapy [97]. The composition of the gut microbiome has been associated with response to ICI in pre-clinical models $[98,99]$. In melanoma murine models, commensal Bifidobacterium has been reported to promote the efficacy of anti-PD-L1 therapy by augmenting the function of DCs leading to CTL priming and infiltration [98]. Recent studies in melanoma, lung and kidney cancer patients have demonstrated association of commensal gut microbiome with response to ICI and fecal transplant from responding patients in germ-free mice resulted in enhanced anti-tumor response [100-103]. In melanoma patients responding to ICI, more abundant species included Bifidobacterium, Collinsella, Enterococcus, Clostridiales, Rominococcus and Faecalibacterium while low levels of Akkermansia muciniphila were observed in epithelial cancers not responding to ICI [100-102]. Patients with a favorable gut microbiota had increased expression of cytolytic $\mathrm{T}$ cell markers, antigen processing and presentation, and increased ratio of $\mathrm{CD}^{+}$CTLs to FoxP3 $^{+} \mathrm{CD}^{+}$Tregs [104]. Modulation of gut microbiome can augment anti-tumor immunotherapy; however, there are several challenges including optimal composition of gut microbiome and therapeutic strategy to achieve that composition.

\section{Matrix remodeling and the inflamed immune microenvironment: untapped predictive and therapeutic potential}

The tumor microenvironment (TME) is an intricate milieu of cells hosting the tumor, including endothelial, mesenchymal and immune cells, along with the extracellular matrix (ECM) [105]. Both cellular and extracellular components of the TME play a pivotal role in tumor growth and metastasis [60], and matrix remodeling has an established role in tumor progression and invasion [106, 107]. Profiling of evolving TME in the ovarian cancer metastases revealed a distinct ECM-associated molecular signature comprising of 22 matrisome genes that predicted poor overall survival in 13 solid tumors suggesting a common and potentially targetable matrix response that influences the course of disease [108]. However, the contribution of the ECM remodeling in shaping the inflammatory and immune milieu of the tumor is only beginning to be systematically explored. (Fig. 1)

\section{Immune-cell trafficking in the TME: mechanisms and impact on immunotherapy responses}

The trafficking of CTLs, Tregs and immune-suppressive myeloid cells is dependent on several factors encountered in the ECM, including matrix components, vascular endothelial cells and cell surface glycoproteins [105, 109]. Leakiness of tumor blood vessels regulated by endothelial cells and pericytes is important for cellular migration, including tumor-infiltrating immune cells [110]. Endothelial cells of the blood and lymphatic vessels proliferate in response to vascular endothelial growth factor (VEGF) resulting in neoangiogenesis [111, 112]. Angiogenic growth factors, including VEGF, decrease the expression of cell surface glycoproteins, including selectins, and intercellular and vascular cell adhesion molecules (ICAM-1 \& 2 and VCAM-1) that mediate cell-cell surface interactions critical for CTL infiltration [110, 113]. Although endothelial cells impair CTL infiltration, they selectively promote transmigration of Tregs by upregulation of specific adhesion molecules and receptors like common lymphatic endothelial and vascular endothelial receptor-1 (CLEVER-1) [114, 115]. In renal cell carcinoma, inhibition of VEGF has resulted in improved survival through decrease of tumor-infiltrating Tregs and MDSCs [116, 117]. In renal cancer, combined PD-1 and VEGF blockade resulted in a response rate of $73 \%$, almost double the response rates seen with ICI monotherapy [118]. VEGF inhibits T-cell development in thymus and VEGF blockade induces preferential commitment of lymphoid progenitors to the $\mathrm{T}$ lineage [119]. VEGF-A is proangiogenic but also plays a key role in immune modulation. VEGF-A enhances PD-1 expression on VEGFRexpressing $\mathrm{CD}^{+} \mathrm{T}$ cells, and promotes an immunosuppressive TME by inhibition of DC maturation and induction of Tregs and MDSCs [120]. VEGF-A blockade inhibits Treg proliferation in colorectal cancer [121]. In melanoma murine models, a combination of PD-1 with VEGF-A blockade induced a strong and synergic anti-tumor effect in tumors expressing high levels of VEGF-A [120]. Decreased VEGF-A gene expression has been observed in melanoma patients responding to ICI [40].

ECM cytoskeleton remodeling, structural plasticity and mechanical forces are increasingly recognized as crucial factors in immune cell trafficking, activation and immunological synapse formation [122]. Density of ECM and basement membrane composition is regulated by stromal matrix components and plays a key role in immune cell migration and spatial distribution [123, 124]. DCs and T cells are able to migrate along collagen type 1 fibrils independent of integrins and adhesion molecules whereas tumor and mesenchymal cells use protease and integrin-dependent migration as they are not able to penetrate dense fibrils [125-127]. In lung cancer, chemokine-dependent $\mathrm{T}$ cell infiltration occurs in loose fibronectin and collagen regions whereas it is impaired in dense matrix fibers surrounding tumor islets, leading to preferential stromal $\mathrm{T}$ cell accumulation and restricted tumor infiltration [128]. Hyaluronan interacts with $\mathrm{T}$ cells to facilitate adhesion and migration and this interaction is prevented by versican, highlighting interplay of stromal ECM components in leukocyte trafficking [129]. 


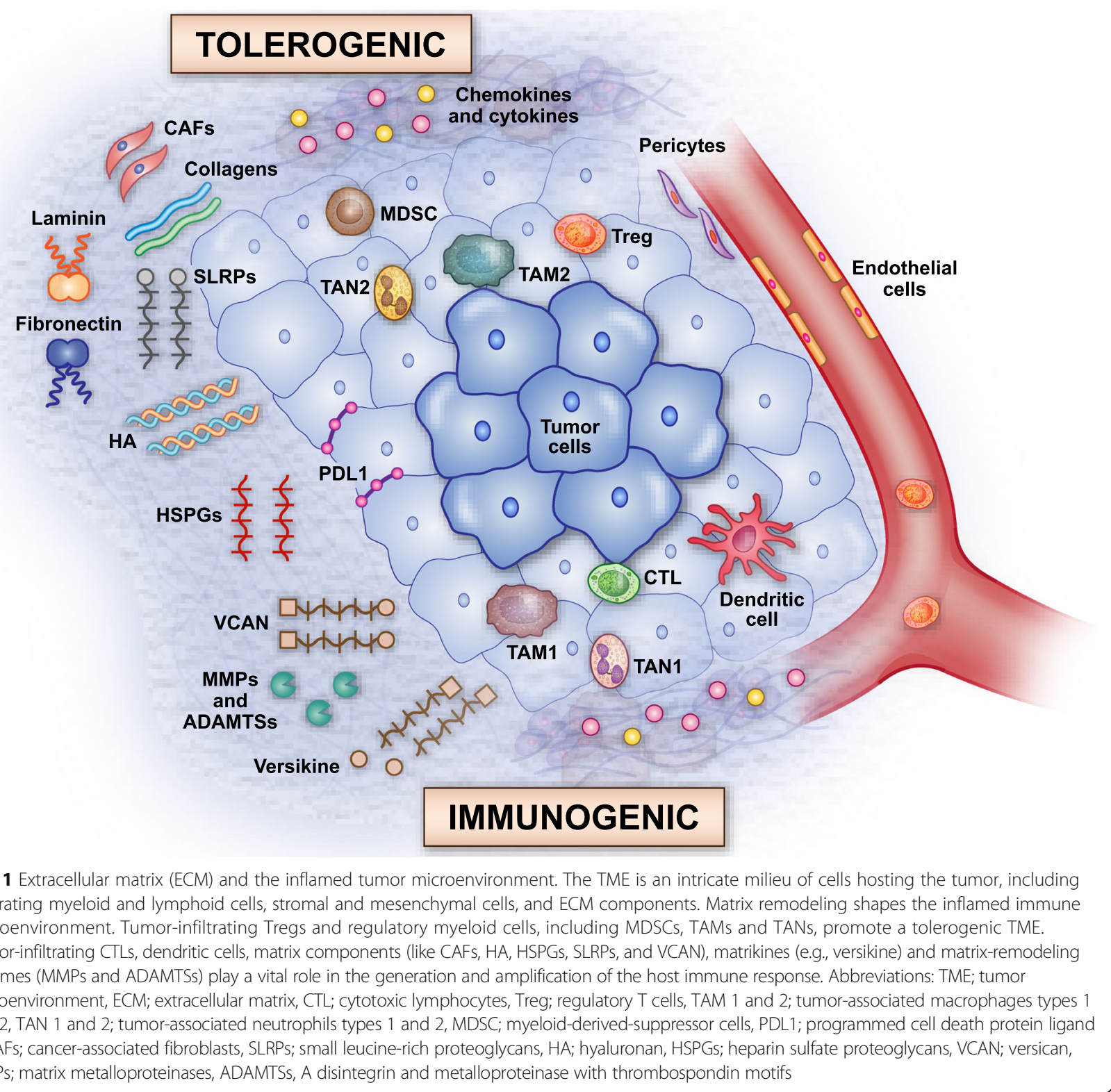

Stromal and matrix-producer cells in the TME: immunomodulatory roles

Matrix components in the TME are produced by mesenchymal stem cells (MSCs), pericytes and cancer-associated fibroblasts (CAFs). Tumor-associated MSCs promote tumor growth and differentiate into pericytes and CAFs in response to stromal growth factors, including platelet-derived growth factor- $\beta$ (PDGF- $\beta$ ) and fibroblast growth factors (FGF) [130, 131]. Pericytes promote structural dysfunction of blood vessels and suppress host immune response. In melanoma and colon cancer, pericytes promote $\mathrm{T}$ cell anergy [132]. In hepatocellular carcinoma, pericytes upregulate angiogenesis and facilitate the influx of immune suppressive cells [133]. In glioma, increase in pericytes results in decreased CTLs [134]. In melanoma, reduction in pericytes results in tumor infiltration of CTLs [135].

CAFs regulate the stromal matrix and serve as a primary source of matrix-associated proteins $[131,136]$. CAFs express chemokines of CXC and CC family and cytokines of IL, IFN and TGF- $\beta$ family. These orchestrate the immune-cell crosstalk and play an essential role in the infiltration of leukocytes in TME [105]. In gastric and colon cancer models, fibroblast activation protein- $\alpha$ (FAP $)^{+}$CAFs correlate with an immune suppressive phenotype, with increased CCL2 expression and decreased IFN-gamma and granzyme-B expression, promoting resistance to ICI therapy that is reversed by $\mathrm{FAP}^{+}$CAF inhibition $[137,138]$. However, in pancreatic cancer models, inhibition of CAFs resulted 
in immune suppression through infiltration of Tregs and increased tumor metastasis through disruption of the stromal fabric $[139,140]$. Matrix stiffness by dense deposition of CAFs and shear stress has shown to activate the TGF- $\beta$ pathway [141]. TGF- $\beta$ in turn, modulates fibroblasts, collagens, and matrix enzymes to exert pleiotropic functional effects by either dampening or promoting $\mathrm{T}$ cell responses [131, 142, 143]. TGF- $\beta$ also promotes metastasis by driving epithelial-to-mesenchymal transition [144].

\section{Extracellular matrix components and their role in tumor inflammation and tumor innate sensing}

The extracellular matrix consists of hundreds of different components that together constitute the matrisome, including collagens, glycoproteins, and proteoglycans [145]. About one-third of matrisome proteins are tissue-specific both in normal and tumor extracellular matrix [146].

\section{Collagens}

Collagens provide tensile strength to the stroma and basement membrane. Collagen deposition is primarily mediated by fibroblasts and has a critical role in tumorigenesis and immune modulation. In colorectal cancer, tumor invasion and growth by increased collagen deposition and cross-linking has been observed [147]. Collagens act as functional ligands for the immune inhibitory receptor, Leukocyte Associated Ig-like Receptor-1 (LAIR-1), and tumor-expressed collagens can trigger immune inhibitory signaling via LAIR-1 [148].

\section{Glycoproteins}

There are several matrisome glycoproteins that mediate cellular interactions and define the structure of a tissue along with collagens. Laminins form the basement membrane that is a potentially important barrier to infiltration of immune cells in the matrix. Laminins, especially laminin $411(\alpha 4)$ and $511(\alpha 5)$, modulate migration and polarization of the leukocytes [149]. A higher ratio of laminin- $\alpha 4$ to laminin- $\alpha 5$ was seen in immune-tolerant lymph nodes and reducing laminin- $\alpha 4$ induced immunemediated rejection in organ transplant murine models [150]. Laminin- $\alpha 5$ have been shown to inhibit leukocyte transmigration [151]. Laminins, in particular laminin 511 , regulate structural intregrity of basement membrane and promote epithelial-to-mesenchymal transition (EMT) resulting in tumor invasion and metastases $[152,153]$. Fibronectin and elastin comprise the interstitial matrix and are modulated by fibroblasts. Fibronectin is upregulated by angiogenic growth factors including VEGF. In lung cancer and melanoma pre-metastatic niches, hematopoietic cells bind with fibronectin via an integrin, VLA-4 (Very Late Antigen-4, CD49d/CD29), to form cellular clusters that precede the arrival of tumor cells, providing a permissive microenvironment for tumor growth [154].

\section{Glucosaminoglycans}

Glycosaminoglycans, including hyaluronan (HA), heparin, heparan sulfate, and chondroitin sulfate, are key macromolecules that affect cell migration and growth by acting directly on cell receptors or via interactions with growth factors [155]. HA is an abundant component of the matrix that modulates immune cells, by interactions with TLRs and CD44, and influences tumor growth via regulation of cellular differentiation and angiogenesis [156]. HA give dense architecture to TME impeding the infiltration of drugs and effector immune cells [157]. Functions of HA vary according to the size. Low molecular weight HA induces inflammation and angiogenesis, inhibits fibroblast differentiation and stimulates pattern-recognition receptors [156, 158-160]. High molecular weight HA is anti-angiogenic, promotes structural integrity, and suppresses the immune system by increasing activity of Tregs $[156,160,161]$.

\section{Proteoglycans}

Proteoglycans contain repeating glycosaminoglycans that bind several cytokines and growth factors in the matrix. Heparan sulfate proteoglycans (HSPGs), including transmembrane (syndecan), glycosylphosphatidylinisotol (GPI)anchored (glypican), secretory granule-derived (serglycin) and secreted HSPGs (perlecan, agrin and betaglycan), are large heterogeneous molecules that interact with growth factors, chemokines and structural proteins of the ECM to influence cellular differentiation and tumor progression [162-164]. Enzymatic degradation of HSPGs has been demonstrated to promote tumor infiltration and antitumor activity of chimeric antigen receptor (CAR)-T cells [165]. Small leucine-rich proteoglycans (SLRPs), include decorin, biglycan, fibromodulin, podocan, keratocan, and others. SLRPs can bind collagens and other matrix components; modulate immune cells by TLR, tumor necrosis factor-alpha (TNF $\alpha$ ), and TGF- $\beta$ pathways; and influence tumor growth and matrix remodeling by interaction with growth factors to modulate cellular differentiation and proliferation [166].

Versican (VCAN), a chondroitin sulfate proteoglycan, is normally present in small quantities in soft tissues but it accumulates in the inflamed cancerous and noncancerous tissues [167]. It interacts with cells and stromal matrix components to regulate cell proliferation, migration, and activation. VCAN accumulation induces inflammation, and recruits and activates immune-suppressive myeloid cells [168-173]. It exerts tolerogenic effects by binding to TLR-2 in the tumor-infiltrating myeloid cells to promote immune evasion and tumor progression $[26,168,174-177]$. Increased stromal VCAN is associated 
with a decrease in tumor-infiltrating CTLs [178]. VCAN along with HA promotes neoangiogenesis in breast cancer [179]. High VCAN expression results in enhanced tumor invasion in gastric and cervical cancers $[178,180]$.

\section{Matrikines and matrix-remodeling enzymes: emerging players in anti-tumor immunity and immunotherapy} Cleavage of matrisome proteins by matrix-remodeling enzymes generates a wide variety of bioactive peptide fragments, the matrikines, which may act as chemokines or cytokines. Matrix metalloproteinases (MMPs) and adamalysins, including A disintegrin and metalloproteinases (ADAM) and A disintegrin and metalloproteinase with thrombospondin motifs (ADAMTS), are major families of the matrix enzymes that produce matrikines, many of which have unknown functions [106, 181].

Matrikines have a critical role in the infiltration of immune cells in TME and interact with immune regulators like TLRs. Elastin-derived matrikines act as chemokines for fibroblasts and up-regulate collagenase in lung cancer cells [182]. Collagen-derived fragments act as chemokines for immune cells and regulate the production of interleukins, in particular, IL-1 $\beta$ [183]. Laminin fragments influence EMT [184]. HA fragments promote inflammation in the TME by signaling through TLRs [160]. VCAN proteolysis, primarily by stromal cell-derived ADAMTS1, generates bioactive fragments, including versikine. It was shown to exert immune modulatory effects, by expression of inflammatory cytokines, IL1 $\beta$ and IL6, and T-cell chemoattractant, CCL2, in the myeloma niche [185]. VCAN proteolysis is associated with CTL infiltration in colorectal cancer, regardless of mismatch repair status, and versikine promotes $\mathrm{T}$ cell infiltration through regulation of Batf3-DCs [186].

MMPs have been associated with tumor progression and angiogenesis [187]. MMP-2 has been shown to promote tolerogenic polarization of DC through binding of TLR2 [188]. There have been several negative phase III clinical trials of MMP inhibitors, primarily because of non-specificity of drugs and complex context-specific roles of MMPs [189, 190]. ADAMTS genes have been found overexpressed, mutated or epigenetically silenced in several tumor types with varying degree of proteomic expression [191]. ADAMTS-mutated cases have higher chemotherapy response rates and better survival in ovarian cancer [192]. A lower ADAMTS13 gene expression has been associated with poor overall survival in bladder cancer patients who expressed a high level of PD-L1 [193]. Tissue inhibitors of metalloproteinases (TIMPs) antagonize matrix proteases and affect major signaling pathways by regulating proteolytic processing [194]. TIMP1 overexpression or TIMP3 silencing is consistently associated with cancer progression and poor prognosis [195]. Matrix proteases are also regulated by various transcriptional factors, cytokines and growth factors that orchestrate the cellular cross-talk and modulate immune and inflammatory responses [196].

\section{Multiple roles of the ECM in modulating the cancer- immunity cycle}

The cancer-immunity cycle, proposed by Chen and Mellman, provides a critical framework to evaluate anti-tumor immune response. It progresses through the immune-mediated tumor cell death and release of tumor antigens, tumor antigen uptake and presentation, priming and activation of $\mathrm{T}$ cells, trafficking of $\mathrm{T}$ cells, tumor infiltration of T cells and recognition of tumor cells [197]. The sustained immune response depends on the accumulation of immune-stimulatory factors and depletion of inhibitory factors. Matrix remodeling plays a vital role in cancer-immunity cycle by modulating immune regulatory feedback mechanisms. Stromal matrix components alter the immune milieu by several mechanisms and modulate differentiation, migration, infiltration and polarization of immune cells in the TME (Fig. 2).

Matrix-remodeling enzymes and matrikines, including versikine, exert direct effects on immune cell polarization and activation. They interact with immune receptors like TLRs and act as cytokines and chemokines to shape the direction and amplitude of the immune response. Recognition of tumor antigens and priming of CTLs is affected by matrikines via interactions with TLRs and DC function. Versikine appears to have a role in promoting local differentiation of the potent immunostimulator Batf3-cDC subset through IRF8 modulation [185, 186]. Endothelial cells, pericytes and adhesion molecules modulate trafficking and infiltration of leukocytes. CAFs secrete stromal elements, chemokines and cytokines, and activate TGF- $\beta$ pathway that affects the recruitment and activation of myeloid-infiltrating cells. Collagens and glycoproteins, like laminin and fibronectin, regulate transmigration and polarization of immune cells in both lymphoid tissue and TME. Glycosaminoglycans, like HA, and proteoglycans, like HSPGs, SLRPs, and VCAN, support the development of an inflamed TME by diverse mechanisms that regulate activity of Tregs and immune-suppressive myeloid cells. A systematic understanding of matrix remodeling and the inflamed TME generated by stromal elements will help to identify investigational targets for development of novel immune biomarkers and combination immunotherapy.

\section{The case for matrix-based biomarkers: VCAN proteolysis} to predict response to immune-modulating therapy

The detection of VCAN proteolysis in the TME may provide a convenient and reliable immune biomarker that can be utilized across tumor types. Its robust association with "T-cell inflammation" and likely, Batf3-cDC intratumoral density promises to select those patients 


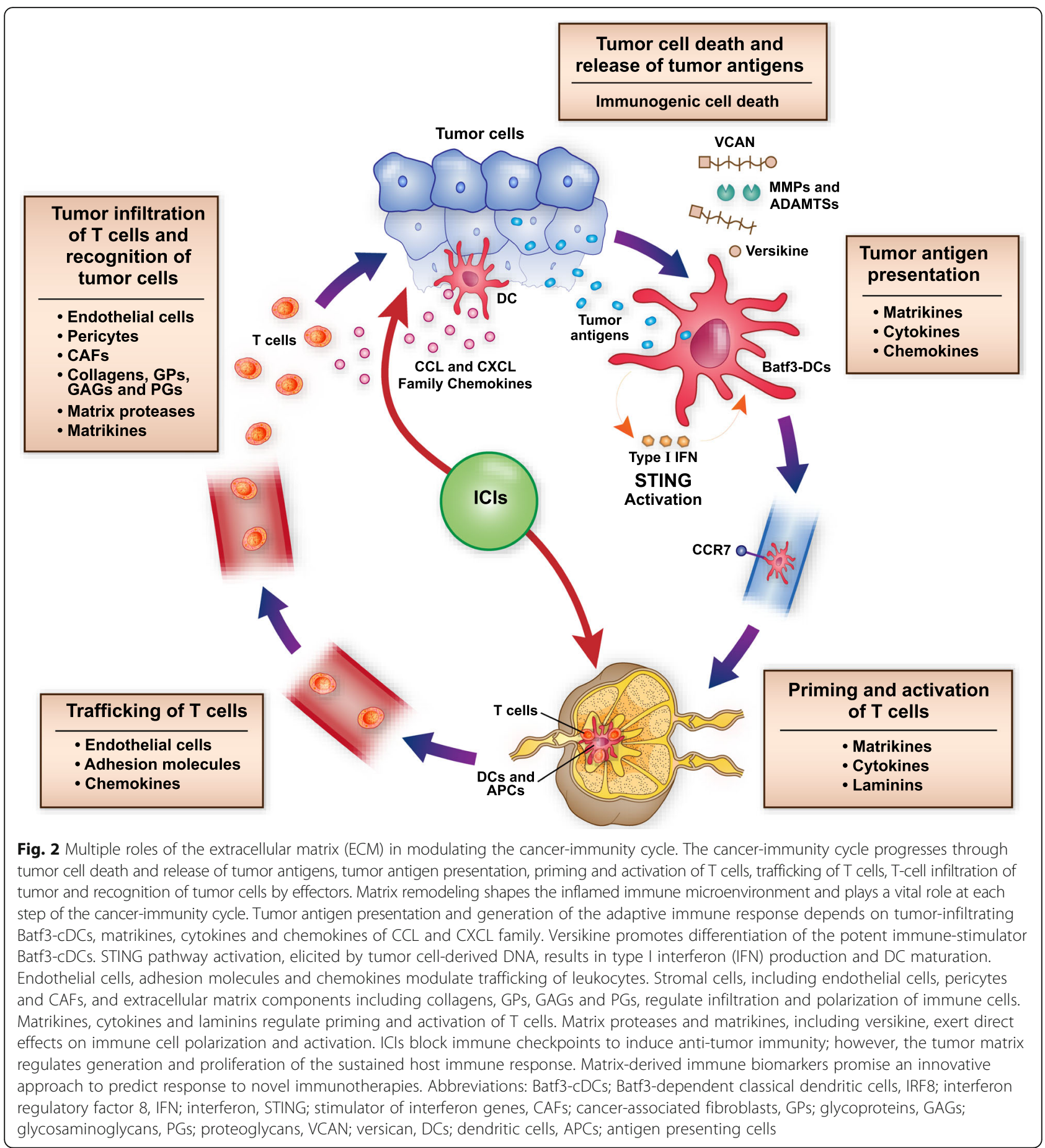

most likely to respond to ICI and other immune-modulating therapies [186]. The regulated proteolysis of VCAN by ADAMTS-metalloproteinases exposes neoepitopes at the cleavage site that can be detected through neoepitope-specific antibodies [185]. Several attractive attributes underscore a potential role for VCAN proteolysis detection in this regard. Firstly, the proteolytic events do not appear to be tumor-specific and may be truly tumor-agnostic $[185,186]$. Secondly, simple immunohistochemistry on standard, paraffin-embedded tissue is used, thus broadening the range of accessible samples to standard diagnostic samples collected in a variety of health care facility settings. Even decalcified tissue (e.g., myeloma bone marrow biopsies that resist attempts at detection of acid-sensitive epitopes such as PD-L1) can be robustly analyzed. Thirdly, the association between 
VCAN proteolysis and T-cell inflammation appears to be independent of neoantigen load- VCAN proteolysis predicted T-cell inflammation in both MSI and MSS colorectal cancers [186].

\section{Conclusions}

The development of novel immunotherapies, including ICIs, was the twenty-first century breakthrough in oncology. Six ICI drugs have been FDA approved and many are in the pipeline. Although there have been durable remissions with the use of ICIs, less than third of the patients derive a benefit from these therapies. An often overlooked facet of immune regulation is the tumor matrix: a diverse and highly dynamic contributor that plays a vital role in the generation and proliferation of the host immune response. Exploring transcriptional imprint and proteomic expression of stromal matrix components may identify promising predictive and prognostic biomarkers. VCAN proteolysis is one emerging paradigm of matrix remodeling and immune modulation. Matrix-derived immune biomarkers promise to generate novel approaches to improve patient stratification and optimize therapeutic strategies employing novel immunotherapies.

\section{Abbreviations}

ADAM: Adamalysins, including A disintegrin and metalloproteinases; ADAMTS: A disintegrin and metalloproteinase with thrombospondin motifs; CAR: Chimeric antigen receptor; CLEVER-1: Common lymphatic endothelial and vascular endothelial receptor 1; CTL: Cytotoxic lymphocytes (CD8 ${ }^{+}$); CTLA-4: Cytotoxic T lymphocyte antigen 4; CAFs: Cancer-associated fibroblasts; cDCs: Classical dendritic cells; DCs: Dendritic cells; ECM: Extracellular matrix; EMT: Epithelial-to-mesenchymal transition; FAP: Fibroblast activation protein; FGF: Fibroblast growth factors; FcyRs: Fc-gamma receptors; FDA: Food and Drug Administration; FOXP3: Forkhead-box P3; GPI: Glycosylphosphatidylinisotol; HA: Hyaluronan; HSPGs: Heparin sulfate proteoglycans; ICl: Immune checkpoint inhibitor; ICAM: Intercellular cell adhesion molecules; IFN: Interferons; IL: Interleukins; IL2Ra: Interleukin-2 receptor chair-alpha; LAIR-1: Leukocyte Associated Ig-like Receptor-1; MMPs: Matrix metalloproteinases; MSCs: Mesenchymal stem cells; mAb: Monoclonal antibodies; MSI: Microsatellite instability; MSS: Microsatellite-stable; MDSCs: Myeloid-derived-suppressor cells; NSCLC: Non-small cell lung cancer; pDCs: Plasmacytoid dendritic cells; PDGF$\beta$ : Platelet-derived growth factor- $\beta$; PD-1: Programmed cell death protein 1; PDL1: Programmed cell death protein ligand 1; PD-L2: Programmed cell death protein ligand 2; SLRPs: Small leucine-rich proteoglycans; Tregs: Regulatory T cells $\left(\mathrm{CD4}^{+}\right)$; TIMPs: Tissue inhibitors of metalloproteinases; TNFa: tumor necrosis factor-alpha; TCR: T cell receptor; TLR: Toll-like receptor; TGF- $\beta$ : Transforming growth factor-beta; TME: Tumor microenvironment; TAMs: Tumor-associated macrophages; TANs: Tumor-associated neutrophils; VCAM: Vascular cell adhesion molecules; VCAN: Versican; VEGF: Vascular endothelial growth factor; VLA-4: Very Late Antigen-4

\section{Acknowledgments}

The authors wish to thank members of the Paul Sondel, Dusty Deming, Doug McNeel, Peiman Hematti, Jenny Gumperz, Mario Otto, Christian Capitini and Shigeki Miyamoto laboratories, all at UW-Madison, for continued and valuable collaboration and discussion of the concepts delineated in this manuscript.

\section{Funding}

Work in the authors' laboratory is supported by the American Cancer Society, the Leukemia and Lymphoma Society, the UW Trillium Myeloma Fund and the $\mathrm{NIH}$.

\section{Availability of data and materials}

Data sharing is not applicable to this article as no datasets were generated or analysed during the current study.

\section{Authors' contributions}

MUM and FA contributed in conception, preparation, review and editing of the manuscript. AP1, AP2, EF, ZM and SGC edited and commented on the manuscript. All authors read and approved the final manuscript.

Ethics approval and consent to participate

Not applicable

\section{Consent for publication}

Not applicable

\section{Competing interests}

The authors declare that they have no competing interests.

\section{Publisher's Note}

Springer Nature remains neutral with regard to jurisdictional claims in published maps and institutional affiliations.

Received: 16 March 2018 Accepted: 15 June 2018

Published online: 03 July 2018

\section{References}

1. Fallarino F, Fields PE, Gajewski TF. B7-1 engagement of cytotoxic T lymphocyte antigen 4 inhibits T cell activation in the absence of CD28. J. Exp. Med. 1998;188(1):205-10.

2. Linsley PS, Greene JL, Brady W, Bajorath J, Ledbetter JA, Peach R. Human B7-1 (CD80) and B7-2 (CD86) bind with similar avidities but distinct kinetics to CD28 and CTLA-4 receptors. Immunity. 1994;1 (9):793-801.

3. Parry RV, Chemnitz JM, Frauwirth KA, Lanfranco AR, Braunstein I, Kobayashi SV, Linsley PS, Thompson CB, Riley JL. CTLA-4 and PD-1 receptors inhibit Tcell activation by distinct mechanisms. Mol. Cell. Biol. 2005;25(21):9543-53.

4. Dong H, Zhu G, Tamada K, Chen L. B7-H1, a third member of the B7 family, co-stimulates T-cell proliferation and interleukin-10 secretion. Nat. Med. 1999;5(12):1365-9

5. Freeman GJ, Long AJ, Iwai Y, Bourque K, Chernova T, Nishimura H, Fitz LJ, Malenkovich N, Okazaki T, Byrne MC, et al. Engagement of the PD-1 immunoinhibitory receptor by a novel B7 family member leads to negative regulation of lymphocyte activation. J. Exp. Med. 2000;192(7):1027-34.

6. Latchman Y, Wood CR, Chernova T, Chaudhary D, Borde M, Chernova I, Iwai Y, Long AJ, Brown JA, Nunes R, et al. PD-L2 is a second ligand for PD-1 and inhibits T cell activation. Nat. Immunol. 2001;2(3):261-8.

7. Tseng SY, Otsuji M, Gorski K, Huang X, Slansky JE, Pai SI, Shalabi A, Shin T, Pardoll DM, Tsuchiya H. B7-DC, a new dendritic cell molecule with potent costimulatory properties for T cells. J. Exp. Med. 2001;193(7):839-46.

8. Iwai Y, Ishida M, Tanaka Y, Okazaki T, Honjo T, Minato N. Involvement of PD-L1 on tumor cells in the escape from host immune system and tumor immunotherapy by PD-L1 blockade. Proc. Natl. Acad. Sci. U. S. A. 2002;99(19):12293-7.

9. Topalian SL, Drake CG, Pardoll DM. Immune checkpoint blockade: a common denominator approach to cancer therapy. Cancer cell. 2015;27(4):450-61.

10. Tumeh $P C$, Harview $C L$, Yearley JH, Shintaku IP, Taylor EJ, Robert L, Chmielowski B, Spasic M, Henry G, Ciobanu V, et al. PD-1 blockade induces responses by inhibiting adaptive immune resistance. Nature. 2014;515(7528):568-71.

11. Hodi FS, O'Day SJ, McDermott DF, Weber RW, Sosman JA, Haanen JB, Gonzalez R, Robert C, Schadendorf D, Hassel JC, et al. Improved Survival with Ipilimumab in Patients with Metastatic Melanoma. N. Engl. J. Med. 2010;363(8):711-23.

12. Powles T, O'Donnell PH, Massard C, et al. Efficacy and safety of durvalumab in locally advanced or metastatic urothelial carcinoma: Updated results from a phase 1/2 open-label study. JAMA Oncol. 2017;3(9):e172411.

13. Antonia SJ, Villegas A, Daniel D, Vicente D, Murakami S, Hui R, Yokoi T, Chiappori A, Lee KH, de Wit M, et al. Durvalumab after Chemoradiotherapy in Stage III Non-Small-Cell Lung Cancer. N. Engl. J. Med. 2017;377(20):1919-29.

14. Kaufman HL, Russell J, Hamid O, Bhatia S, Terheyden P, D'Angelo SP, Shih KC, Lebbé C, Linette GP, Milella M, et al. Avelumab in patients with chemotherapy-refractory metastatic Merkel cell carcinoma: a multicentre, single-group, open-label, phase 2 trial. Lancet Oncol. 2016;17(10):1374-85. 
15. Larkin J, Chiarion-Sileni V, Gonzalez R, Grob JJ, Cowey CL, Lao CD, Schadendorf D, Dummer R, Smylie M, Rutkowski P, et al. Combined Nivolumab and Ipilimumab or Monotherapy in Untreated Melanoma. N. Engl. J. Med. 2015;373(1):23-34.

16. Robert C, Long GV, Brady B, Dutriaux C, Maio M, Mortier L, Hassel JC, Rutkowski $P$, McNeil C, Kalinka-Warzocha E, et al. Nivolumab in Previously Untreated Melanoma without BRAF Mutation. N. Engl. J. Med. 2015;372(4):320-30

17. Schachter J, Ribas A, Long GV, Arance A, Grob JJ, Mortier L, Daud A, Carlino MS, McNeil CM, Lotem M, et al. Pembrolizumab versus ipilimumab for advanced melanoma: Final overall survival analysis of KEYNOTE-006. J. Clin. Oncol. 2016;34(15_suppl):9504.

18. Wolchok JD, Kluger H, Callahan MK, Postow MA, Rizvi NA, Lesokhin AM, Segal NH, Ariyan CE, Gordon R-A, Reed K, et al. Nivolumab plus Ipilimumab in Advanced Melanoma. N. Engl. J. Med. 2013;369(2):122-33.

19. Borghaei H, Paz-Ares L, Horn L, Spigel DR, Steins M, Ready NE, Chow LQ, Vokes EE, Felip E, Holgado E, et al. Nivolumab versus Docetaxel in Advanced Nonsquamous Non-Small-Cell Lung Cancer. N. Engl. J. Med. 2015;373(17):1627-39.

20. Brahmer J, Reckamp KL, Baas P, Crino L, Eberhardt WE, Poddubskaya E, Antonia S, Pluzanski A, Vokes EE, Holgado E, et al. Nivolumab versus Docetaxel in Advanced Squamous-Cell Non-Small-Cell Lung Cancer. N. Engl. J. Med. 2015:373(2):123-35.

21. Herbst RS, Baas P, Kim DW, Felip E, Perez-Gracia JL, Han JY, Molina J, Kim JH, Arvis CD, Ahn MJ, et al. Pembrolizumab versus docetaxel for previously treated, PD-L1-positive, advanced non-small-cell lung cancer (KEYNOTE-010): a randomised controlled trial. Lancet. 2016;387(10027):1540-50.

22. Rittmeyer A, Barlesi F, Waterkamp D, Park K, Ciardiello F, von Pawel J, Gadgeel SM, Hida T, Kowalski DM, Dols MC, et al. Atezolizumab versus docetaxel in patients with previously treated non-small-cell lung cancer (OAK): a phase 3, open-label, multicentre randomised controlled trial. Lancet. 2017:389(10066):255-65.

23. Overman MJ, McDermott R, Leach JL, Lonardi S, Lenz H-J, Morse MA, Desai J. Hill A, Axelson M, Moss RA, et al. Nivolumab in patients with metastatic DNA mismatch repair-deficient or microsatellite instability-high colorectal cancer (CheckMate 142): an open-label, multicentre, phase 2 study. Lancet Oncol. 2017;18(9):1182-91.

24. Ferris RL, Blumenschein G Jr, Fayette J, Guigay J, Colevas AD, Licitra L, Harrington K, Kasper S, Vokes EE, Even C, et al. Nivolumab for Recurrent Squamous-Cell Carcinoma of the Head and Neck. N. Engl. J. Med. 2016; 375(19):1856-67.

25. Motzer RJ, Escudier B, McDermott DF, George S, Hammers HJ, Srinivas S, Tykodi SS, Sosman JA, Procopio G, Plimack ER, et al. Nivolumab versus Everolimus in Advanced Renal-Cell Carcinoma. N. Engl. J. Med. 2015;373(19):1803-13.

26. Ansell SM, Lesokhin AM, Borrello I, Halwani A, Scott EC, Gutierrez M, Schuster SJ, Millenson MM, Cattry D, Freeman GJ, et al. PD-1 Blockade with Nivolumab in Relapsed or Refractory Hodgkin's Lymphoma. N. Engl. J. Med. 2015;372(4):311-9.

27. Daver N, Basu S, Garcia-Manero G, Cortes JE, Ravandi F, Jabbour EJ, Hendrickson S, Pierce S, Ning J, Konopleva M, et al. Phase IB/II Study of Nivolumab in Combination with Azacytidine (AZA) in Patients (pts) with Relapsed Acute Myeloid Leukemia (AML). Blood. 2016;128(22):763.

28. Cimino-Mathews A, Thompson E, Taube JM, Ye X, Lu Y, Meeker A, Xu H, Sharma R, Lecksell K, Cornish TC, et al. PD-L1 (B7-H1) expression and the immune tumor microenvironment in primary and metastatic breast carcinomas. Hum. Pathol. 2016;47(1):52-63.

29. Lipson EJ, Vincent JG, Loyo M, Kagohara LT, Luber BS, Wang H, Xu H, Nayar SK, Wang TS, Sidransky D, et al. PD-L1 expression in the Merkel cell carcinoma microenvironment: association with inflammation, Merkel cell polyomavirus and overall survival. Cancer Immunol. Res. 2013;1(1):54-63.

30. Schalper KA, Velcheti V, Carvajal D, Wimberly H, Brown J, Pusztai L, Rimm DL. In situ tumor PD-L1 mRNA expression is associated with increased TILs and better outcome in breast carcinomas. Clin. Cancer Res. 2014;20(10):2773-82.

31. Taube JM, Young GD, McMiller TL, Chen S, Salas JT, Pritchard TS, Xu H, Meeker AK, Fan J, Cheadle C, et al. Differential Expression of ImmuneRegulatory Genes Associated with PD-L1 Display in Melanoma: Implications for PD-1 Pathway Blockade. Clin. Cancer Res. 2015;21(17):3969-76.

32. Velcheti V, Schalper KA, Carvajal DE, Anagnostou VK, Syrigos KN, Sznol M, Herbst RS, Gettinger SN, Chen L, Rimm DL. Programmed death ligand-1 expression in non-small cell lung cancer. Lab Invest. 2014;94(1):107-16.

33. Le DT, Uram JN, Wang H, Bartlett BR, Kemberling $H$, Eyring AD, Skora AD, Luber BS, Azad NS, Laheru D, et al. PD-1 Blockade in Tumors with Mismatch-Repair Deficiency. N. Engl. J. Med. 2015;372(26):2509-20.
34. Rizvi NA, Hellmann MD, Snyder A, Kvistborg P, Makarov V, Havel JJ, Lee W, Yuan J, Wong P, Ho TS, et al. Cancer immunology. Mutational landscape determines sensitivity to PD-1 blockade in non-small cell lung cancer. Science. 2015;348(6230):124-8.

35. Topalian SL, Taube JM, Anders RA, Pardoll DM. Mechanism-driven biomarkers to guide immune checkpoint blockade in cancer therapy. Nat Rev Cancer. 2016;16(5):275-87.

36. Topalian SL, Hodi FS, Brahmer JR, Gettinger SN, Smith DC, McDermott DF, Powderly JD, Carvajal RD, Sosman JA, Atkins MB, et al. Safety, Activity, and Immune Correlates of Anti-PD-1 Antibody in Cancer. N. Engl. J. Med. 2012;366(26):2443-54.

37. Garon EB, Rizvi NA, Hui R, Leighl N, Balmanoukian AS, Eder JP, Patnaik A, Aggarwal C, Gubens M, Horn L, et al. Pembrolizumab for the Treatment of Non-Small-Cell Lung Cancer. N. Engl. J. Med. 2015;372(21):2018-28.

38. Jessurun CAC, Vos JAM, Limpens J, Luiten RM. Biomarkers for Response of Melanoma Patients to Immune Checkpoint Inhibitors: A Systematic Review. Front. Oncol. 2017;7:233.

39. Mukherji D, Jabbour MN, Saroufim M, Temraz S, Nasr R, Charafeddine M, Assi R, Shamseddine A, Tawil AN. Programmed Death-Ligand 1 Expression in Muscle-Invasive Bladder Cancer Cystectomy Specimens and Lymph Node Metastasis: A Reliable Treatment Selection Biomarker? Clin. Genitourin. Cancer. 2016;14(2):183-7.

40. Chen P-L, Roh W, Reuben A, Cooper ZA, Spencer CN, Prieto PA, Miller JP, Bassett RL, Gopalakrishnan V, Wani K, et al. Analysis of Immune Signatures in Longitudinal Tumor Samples Yields Insight into Biomarkers of Response and Mechanisms of Resistance to Immune Checkpoint Blockade. Cancer Discov. 2016;6(8):827-37.

41. Inoue Y, Yoshimura K, Mori K, Kurabe N, Kahyo T, Mori H, Kawase A, Tanahashi M, Ogawa H, Inui N, et al. Clinical significance of PD-L1 and PD-L2 copy number gains in non-small-cell lung cancer. Oncotarget. 2016;7(22):32113-28.

42. Van Allen EM, Miao D, Schilling B, Shukla SA, Blank C, Zimmer L, Sucker A, Hillen U, Geukes Foppen MH, Goldinger SM, et al. Genomic correlates of response to CTLA-4 blockade in metastatic melanoma. Science. 2015;350(6257):207-11.

43. Hugo W, Zaretsky JM, Sun L, Song C, Moreno BH, Hu-Lieskovan S, Berent-Maoz B, Pang J, Chmielowski B, Cherry G, et al. Genomic and Transcriptomic Features of Response to Anti-PD-1 Therapy in Metastatic Melanoma. Cell. 165(1):35-44.

44. Snyder A, Makarov V, Merghoub T, Yuan J, Zaretsky JM, Desrichard A, Walsh LA, Postow MA, Wong P, Ho TS, et al. Genetic Basis for Clinical Response to CTLA-4 Blockade in Melanoma. N. Engl. J. Med. 2014;371(23):2189-99.

45. McGranahan N, Furness AJ, Rosenthal R, Ramskov S, Lyngaa R, Saini SK, Jamal-Hanjani M, Wilson GA, Birkbak NJ, Hiley CT, et al. Clonal neoantigens elicit T cell immunoreactivity and sensitivity to immune checkpoint blockade. Science. 2016;351(6280):1463-9.

46. Reuben A, Spencer CN, Prieto PA, Gopalakrishnan V, Reddy SM, Miller JP, Mao X, De Macedo MP, Chen J, Song X, et al. Genomic and immune heterogeneity are associated with differential responses to therapy in melanoma. npj Genom Med. 2017;2(1):10.

47. Shields BD, Mahmoud F, Taylor EM, Byrum SD, Sengupta D, Koss B, Baldin G, Ransom S, Cline K, Mackintosh SG, et al. Indicators of responsiveness to immune checkpoint inhibitors. Sci. Rep. 2017;7(1):807.

48. Drescher KM, Sharma P, Watson P, Gatalica Z, Thibodeau SN, Lynch HT. Lymphocyte recruitment into the tumor site is altered in patients with MSIH colon cancer. Familial cancer. 2009;8(3):231-9.

49. Harlin $H$, Meng $Y$, Peterson AC, Zha $Y$, Tretiakova M, Slingluff C, McKee M, Gajewski TF. Chemokine Expression in Melanoma Metastases Associated with CD8<sup $>+</$ sup $>$ T-Cell Recruitment. Cancer Res. 2009:69(7):3077-85.

50. Roh W, Chen P-L, Reuben A, Spencer CN, Prieto PA, Miller JP, Gopalakrishnan V, Wang F, Cooper ZA, Reddy SM, et al. Integrated molecular analysis of tumor biopsies on sequential CTLA-4 and PD-1 blockade reveals markers of response and resistance. Sci Transl Med. 2017;9(379). https://doi.org/10.1126/ scitransImed.aah3560.

51. Wong RM, Scotland RR, Lau RL, Wang C, Korman AJ, Kast WM, Weber JS. Programmed death-1 blockade enhances expansion and functional capacity of human melanoma antigen-specific CTLs. Int. Immunol. 2007; 19(10):1223-34.

52. Gros A, Parkhurst MR, Tran E, Pasetto A, Robbins PF, llyas S, Prickett TD, Gartner JJ, Crystal JS, Roberts IM, et al. Prospective identification of neoantigen-specific lymphocytes in the peripheral blood of melanoma patients. Nat. Med. 2016;22(4):433-8. 
53. Ma W, Gilligan BM, Yuan J, Li T. Current status and perspectives in translational biomarker research for PD-1/PD-L1 immune checkpoint blockade therapy. J. Hematol. Oncol. 2016;9(1):47.

54. Cooper ZA, Reuben A, Spencer CN, Prieto PA, Austin-Breneman JL, Jiang H, Haymaker C, Gopalakrishnan V, Tetzlaff MT, Frederick DT, et al. Distinct clinical patterns and immune infiltrates are observed at time of progression on targeted therapy versus immune checkpoint blockade for melanoma. Oncoimmunology. 2016;5(3):e1136044.

55. Chaudhary B, Elkord E. Regulatory T Cells in the Tumor Microenvironment and Cancer Progression: Role and Therapeutic Targeting. Vaccines. 2016:4(3):28.

56. Lindau D, Gielen P, Kroesen M, Wesseling P, Adema GJ. The immunosuppressive tumour network: myeloid-derived suppressor cells, regulatory T cells and natural killer T cells. Immunology. 2013;138(2): 105-15.

57. Hannani D, Vetizou M, Enot D, Rusakiewicz S, Chaput N, Klatzmann D, Desbois M, Jacquelot N, Vimond N, Chouaib S, et al. Anticancer immunotherapy by CTLA-4 blockade: obligatory contribution of $\mathrm{IL}-2$ receptors and negative prognostic impact of soluble CD25. Cell Res. 2015;25(2):208-24.

58. Wang W, Lau R, Yu D, Zhu W, Korman A, Weber J. PD1 blockade reverses the suppression of melanoma antigen-specific CTL by CD4+ CD25(Hi) regulatory T cells. Int. Immunol. 2009;21(9):1065-77.

59. Liakou Cl, Kamat A, Tang DN, Chen H, Sun J, Troncoso P, Logothetis C, Sharma P. CTLA-4 blockade increases IFNgamma-producing CD4+ICOSh cells to shift the ratio of effector to regulatory $T$ cells in cancer patients. Proc. Natl. Acad. Sci. U. S. A. 2008;105(39):14987-92

60. Asimakopoulos F, Hope C, Johnson MG, Pagenkopf A, Gromek K, Nagel B. Extracellular matrix and the myeloid-in-myeloma compartment: balancing tolerogenic and immunogenic inflammation in the myeloma niche. J Leukoc Biol. 2017;102(2):265-75.

61. Medina-Echeverz J, Aranda F, Berraondo P. Myeloid-derived cells are key targets of tumor immunotherapy. Oncolmmunology. 2014;3(4):e28398.

62. Engblom C, Pfirschke C, Pittet MJ. The role of myeloid cells in cancer therapies. Nat Rev Cancer. 2016;16:447.

63. Gentles AJ, Newman AM, Liu CL, Bratman SV, Feng W, Kim D, Nair VS, $\mathrm{Xu} Y$, Khuong $A$, Hoang $C D$, et al. The prognostic landscape of genes and infiltrating immune cells across human cancers. Nat. Med. 2015; 21(8):938-45.

64. Khaled YS, Ammori BJ, Elkord E. Myeloid-derived suppressor cells in cancer: recent progress and prospects. Immunol Cell Biol. 2013;91(8):493-502.

65. Parker KH, Beury DW, Ostrand-Rosenberg S. Myeloid-Derived Suppressor Cells: Critical Cells Driving Immune Suppression in the Tumor Microenvironment. Adv. Cancer Res. 2015:128:95-139.

66. Gabitass RF, Annels NE, Stocken DD, Pandha HA, Middleton GW. Elevated myeloid-derived suppressor cells in pancreatic, esophageal and gastric cancer are an independent prognostic factor and are associated with significant elevation of the Th2 cytokine interleukin-13. Cancer Immunol Immunother. 2011;60(10):1419-30.

67. Marvel D, Gabrilovich DI. Myeloid-derived suppressor cells in the tumor microenvironment: expect the unexpected. J Clin Invest. 2015;125(9):3356-64.

68. Vasquez-Dunddel D, Pan F, Zeng Q, Gorbounov M, Albesiano E, Fu J, Blosser RL, Tam AJ, Bruno T, Zhang H, et al. STAT3 regulates arginase-I in myeloid-derived suppressor cells from cancer patients. J Clin Invest. 2013;123(4):1580-9.

69. Mazzoni A, Bronte V, Visintin A, Spitzer JH, Apolloni E, Serafini P, Zanovello P, Segal DM. Myeloid suppressor lines inhibit T cell responses by an NO-dependent mechanism. J. Immunol. 2002;168(2):689-95.

70. Mao Y, Poschke I, Wennerberg E, Pico de Coana Y, Egyhazi Brage S, Schultz I, Hansson J, Masucci G, Lundqvist A, Kiessling R. Melanoma-educated CD14 + cells acquire a myeloid-derived suppressor cell phenotype through COX2-dependent mechanisms. Cancer Res. 2013;73(13):3877-87.

71. Nagaraj S, Gupta K, Pisarev V, Kinarsky L, Sherman S, Kang L, Herber DL, Schneck J, Gabrilovich DI. Altered recognition of antigen is a mechanism of CD8+ T cell tolerance in cancer. Nature medicine. 2007;13(7):828-35.

72. Pan PY, Ma G, Weber KJ, Ozao-Choy J, Wang G, Yin B, Divino CM, Chen SH. Immune stimulatory receptor CD40 is required for T-cell suppression and $\mathrm{T}$ regulatory cell activation mediated by myeloid-derived suppressor cells in cancer. Cancer Res. 2010;70(1):99-108

73. Matsui A, Yokoo H, Negishi Y, Endo-Takahashi Y, Chun NA, Kadouchi I, Suzuki R, Maruyama K, Aramaki Y, Semba K, et al. CXCL17 expression by tumor cells recruits CD11b+Gr1 high F4/80- cells and promotes tumor progression. PloS one. 2012;7(8):e44080.
74. Fridlender ZG, Sun J, Kim S, Kapoor V, Cheng G, Ling L, Worthen GS, Albelda SM. Polarization of tumor-associated neutrophil phenotype by TGF-beta: "N1" versus "N2" TAN. Cancer cell. 2009;16(3):183-94.

75. Xue J, Schmidt SV, Sander J, Draffehn A, Krebs W, Quester I, De Nardo D, Gohel TD, Emde M, Schmidleithner L, et al. Transcriptome-based network analysis reveals a spectrum model of human macrophage activation. Immunity. 2014;40(2):274-88.

76. Yang L, Zhang Y. Tumor-associated macrophages: from basic research to clinical application. J. Hematol. Oncol. 2017;10(1):58.

77. Chanmee T, Ontong P, Konno K, Itano N. Tumor-associated macrophages as major players in the tumor microenvironment. Cancers (Basel). 2014;6(3):1670-90.

78. Hurt B, Schulick R, Edil B, El Kasmi KC, Barnett C Jr. Cancer-promoting mechanisms of tumor-associated neutrophils. Am. J. Surg. 2017;214(5):938-44.

79. Huang Y, Snuderl M, Jain RK. Polarization of tumor-associated macrophages: a novel strategy for vascular normalization and antitumor immunity. Cancer cell. 2011;19(1):1-2.

80. Kuang DM, Zhao Q, Peng C, Xu J, Zhang JP, Wu C, Zheng L. Activated monocytes in peritumoral stroma of hepatocellular carcinoma foster immune privilege and disease progression through PD-L1. J. Exp. Med. 2009;206:1327-37.

81. Romano E, Kusio-Kobialka M, Foukas PG, Baumgaertner P, Meyer C, Ballaben P, Michielin O, Weide B, Romero P, Speiser DE. Ipilimumab-dependent cellmediated cytotoxicity of regulatory $T$ cells ex vivo by nonclassical monocytes in melanoma patients. Proc. Natl. Acad. Sci. U. S. A. 2015;112(19):6140-5.

82. Simpson TR, Li F, Montalvo-Ortiz W, Sepulveda MA, Bergerhoff K, Arce F, Roddie C, Henry JY, Yagita H, Wolchok JD, et al. Fc-dependent depletion of tumor-infiltrating regulatory $T$ cells co-defines the efficacy of anti-CTLA-4 therapy against melanoma. J. Exp. Med. 2013;210(9):1695-710.

83. Carretero R, Sektioglu IM, Garbi N, Salgado OC, Beckhove P, Hammerling GJ. Eosinophils orchestrate cancer rejection by normalizing tumor vessels and enhancing infiltration of CD8(+) T cells. Nat. Immunol. 2015;16(6):609-17.

84. Nielsen HJ, Hansen U, Christensen IJ, Reimert CM, Brunner N, Moesgaard F. Independent prognostic value of eosinophil and mast cell infiltration in colorectal cancer tissue. J Pathol. 1999;189(4):487-95.

85. Blatner NR, Bonertz A, Beckhove P, Cheon EC, Krantz SB, Strouch M, Weitz J, Koch M, Halverson AL, Bentrem DJ, et al. In colorectal cancer mast cells contribute to systemic regulatory T-cell dysfunction. Proc. Natl. Acad. Sci. U. S. A. $2010 ; 107(14): 6430-5$.

86. Saleem SJ, Martin RK, Morales JK, Sturgill JL, Gibb DR, Graham L, Bear HD, Manjili MH, Ryan JJ, Conrad DH. Cutting edge: mast cells critically augment myeloid-derived suppressor cell activity. J. Immunol. 2012;189(2):511-5.

87. Yang Z, Zhang B, Li D, Lv M, Huang C, Shen GX, Huang B. Mast cells mobilize myeloid-derived suppressor cells and Treg cells in tumor microenvironment via IL-17 pathway in murine hepatocarcinoma model. PloS one. 2010;5(1):e8922.

88. Anderson DA 3rd, Murphy KM, Briseno CG. Development, Diversity, and Function of Dendritic Cells in Mouse and Human. Cold Spring Harb Perspect Biol. 2017. https://doi.org/10.1101/cshperspect.a028613. [Epub ahead of print]

89. Swiecki M, Colonna M. The multifaceted biology of plasmacytoid dendritic cells. Nature reviews Immunology. 2015;15(8):471-85.

90. Goc J, Germain C, Vo-Bourgais TK, Lupo A, Klein C, Knockaert S, de Chaisemartin L, Ouakrim H, Becht E, Alifano M, et al. Dendritic cells in tumor-associated tertiary lymphoid structures signal a Th1 cytotoxic immune contexture and license the positive prognostic value of infiltrating CD8+ T cells. Cancer Res. 2014;74(3):705-15.

91. Dieu-Nosjean MC, Antoine M, Danel C, Heudes D, Wislez M, Poulot V, Rabbe N, Laurans L, Tartour E, de Chaisemartin L, et al. Long-term survival for patients with non-small-cell lung cancer with intratumoral lymphoid structures. J. Clin. Oncol. Off. J. Am. Soc. Clin. Oncol. 2008;26(27):4410-7.

92. Ladanyi A, Kiss J, Somlai B, Gilde K, Fejos Z, Mohos A, Gaudi I, Timar J. Density of DC-LAMP(+) mature dendritic cells in combination with activated $T$ lymphocytes infiltrating primary cutaneous melanoma is a strong independent prognostic factor. Cancer Immunol. Immunother. 2007;56(9):1459-69.

93. Castino GF, Cortese N, Capretti G, Serio S, Di Caro G, Mineri R, Magrini E, Grizzi F, Cappello P, Novelli F, et al. Spatial distribution of B cells predicts prognosis in human pancreatic adenocarcinoma. Oncoimmunology. 2016;5(4):e1085147.

94. Broz ML, Binnewies M, Boldajipour B, Nelson AE, Pollack JL, Erle DJ, Barczak A, Rosenblum MD, Daud A, Barber DL, et al. Dissecting the tumor myeloid compartment reveals rare activating antigen-presenting cells critical for $T$ cell immunity. Cancer cell. 2014;26(5):638-52. 
95. Spranger S, Bao R, Gajewski TF. Melanoma-intrinsic beta-catenin signalling prevents anti-tumour immunity. Nature. 2015;523(7559):231-5.

96. Pfirschke C, Engblom C, Rickelt S, Cortez-Retamozo V, Garris C, Pucci F, Yamazaki T, Poirier-Colame V, Newton A, Redouane Y, et al. Immunogenic Chemotherapy Sensitizes Tumors to Checkpoint Blockade Therapy. Immunity. 2016:44(2):343-54.

97. Botticelli A, Zizzari l, Mazzuca F, Ascierto PA, Putignani L, Marchetti L, Napoletano C, Nuti M, Marchetti P. Cross-talk between microbiota and immune fitness to steer and control response to anti PD-1/PDL-1 treatment. Oncotarget. 2017;8(5):8890-9.

98. Sivan A, Corrales L, Hubert N, Williams JB, Aquino-Michaels K, Earley ZM, Benyamin FW, Lei YM, Jabri B, Alegre ML, et al. Commensal Bifidobacterium promotes antitumor immunity and facilitates anti-PD-L1 efficacy. Science. 2015;350(6264):1084-9

99. Vetizou M, Pitt JM, Daillere R, Lepage P, Waldschmitt N, Flament C, Rusakiewicz S, Routy B, Roberti MP, Duong CP, et al. Anticancer immunotherapy by CTLA-4 blockade relies on the gut microbiota. Science. 2015;350(6264):1079-84.

100. Matson V, Fessler J, Bao R, Chongsuwat T, Zha Y, Alegre M-L, Luke Jل JلGajewski TF. The commensal microbiome is associated with anti-PD-1 efficacy in metastatic melanoma patients. Science. 2018;359(6371):104-8.

101. Gopalakrishnan V, Spencer CN, Nezi L, Reuben A, Andrews MC, Karpinets TV, Prieto PA, Vicente D, Hoffman K, Wei SC, et al. Gut microbiome modulates response to anti-PD-1 immunotherapy in melanoma patients. Science. 2018;359(6371):97-103

102. Routy B, Le Chatelier E, Derosa L, Duong CPM, Alou MT, Daillère R, Fluckiger A, Messaoudene M, Rauber C, Roberti MP, et al. Gut microbiome influences efficacy of PD-1-based immunotherapy against epithelial tumors. Science. 2018;359(6371):91-7

103. Chaput N, Lepage P, Coutzac C, Soularue E, Le Roux K, Monot C, Boselli L, Routier E, Cassard L, Collins M, et al. Baseline gut microbiota predicts clinical response and colitis in metastatic melanoma patients treated with ipilimumab. Ann. Oncol. 2017;28(6):1368-79.

104. Gopalakrishnan V, Helmink BA, Spencer CN, Reuben A, Wargo JA. The Influence of the Gut Microbiome on Cancer, Immunity, and Cancer Immunotherapy. Cancer cell. 2018;33(4):570-80

105. Turley SJ, Cremasco V, Astarita JL. Immunological hallmarks of stromal cells in the tumour microenvironment. Nat Rev Immunol. 2015:15(11):669-82.

106. Bonnans C, Chou J, Werb Z. Remodelling the extracellular matrix in development and disease. Nat. Rev. Mol. Cell Biol. 2014;15(12):786-801.

107. Jiang D, Lim SY. Influence of Immune Myeloid Cells on the Extracellular Matrix During Cancer Metastasis. Cancer Microenviron. 2016;9(1):45-61.

108. Pearce OMT, Delaine-Smith RM, Maniati E, Nichols S, Wang J, Böhm S, Rajeeve V, Ullah D, Chakravarty P, Jones RR, et al. Deconstruction of a Metastatic Tumor Microenvironment Reveals a Common Matrix Response in Human Cancers. Cancer Discov. 2018;8(3):304-19.

109. Boyd DF, Thomas PG. Towards integrating extracellular matrix and immunological pathways. Cytokine. 2017;98:79-86.

110. Castermans K, Griffioen AW. Tumor blood vessels, a difficult hurdle for infiltrating leukocytes. Biochim. Biophys. Acta. 2007;1776(2):160-74

111. Achen MG, McColl BK, Stacker SA. Focus on lymphangiogenesis in tumor metastasis. Cancer cell. 2005;7(2):121-7.

112. Lund AW, Swartz MA. Role of lymphatic vessels in tumor immunity: passive conduits or active participants? J. Mammary Gland Biol. Neoplasia. 2010;15(3):341-52

113. Griffioen AW, Damen CA, Blijham GH, Groenewegen G. Tumor angiogenesis is accompanied by a decreased inflammatory response of tumor-associated endothelium. Blood. 1996;88(2):667-73.

114. Nummer D, Suri-Payer E, Schmitz-Winnenthal H, Bonertz A, Galindo L, Antolovich D, Koch M, Buchler M, Weitz J, Schirrmacher V, et al. Role of tumor endothelium in CD4+ CD25+ regulatory T cell infiltration of human pancreatic carcinoma. J Natl Cancer Inst. 2007:99(15):1188-99.

115. Shetty S, Weston CJ, Oo YH, Westerlund N, Stamataki Z, Youster J, Hubscher SG, Salmi M, Jalkanen S, Lalor PF, et al. Common lymphatic endothelial and vascular endothelial receptor-1 mediates the transmigration of regulatory T cells across human hepatic sinusoidal endothelium. J. Immunol. 2011;186(7):4147-55.

116. Adotevi O, Pere H, Ravel P, Haicheur N, Badoual C, Merillon N, Medioni J, Peyrard S, Roncelin S, Verkarre V, et al. A decrease of regulatory T cells correlates with overall survival after sunitinib-based antiangiogenic therapy in metastatic renal cancer patients. J. Immunother. 2010;33(9):991-8.
117. Ko JS, Zea AH, Rini BI, Ireland JL, Elson P, Cohen P, Golshayan A, Rayman PA, Wood L, Garcia J, et al. Sunitinib mediates reversal of myeloid-derived suppressor cell accumulation in renal cell carcinoma patients. Clin. Cancer Res. 2009:15(6):2148-57.

118. Atkins MB, Plimack ER, Puzanov I, Fishman MN, McDermott DF, Cho DC, Vaishampayan U, George S, Olencki TE, Tarazi JC, et al. Axitinib in combination with pembrolizumab in patients with advanced renal cell cancer: a non-randomised, open-label, dose-finding, and dose-expansion phase 1b trial. Lancet Oncol. 2018;19(3):405-15.

119. Ohm JE, Gabrilovich DI, Sempowski GD, Kisseleva E, Parman KS, Nadaf S, Carbone DP. VEGF inhibits T-cell development and may contribute to tumor-induced immune suppression. Blood. 2003;101(12):4878-86.

120. Voron T, Colussi O, Marcheteau E, Pernot S, Nizard M, Pointet A-L, Latreche S, Bergaya S, Benhamouda N, Tanchot C, et al. VEGF-A modulates expression of inhibitory checkpoints on CD $8<$ sup $>+</$ sup $>T$ cells in tumors. J. Exp. Med. 2015;212(2):139-48

121. Terme M, Pernot S, Marcheteau E, Sandoval F, Benhamouda N, Colussi O, Dubreuil O, Carpentier AF, Tartour E, Taieb J. VEGFA-VEGFR pathway blockade inhibits tumor-induced regulatory T-cell proliferation in colorectal cancer. Cancer Res. 2013;73(2):539-49.

122. Huse M. Mechanical forces in the immune system. Nat. Rev. Immunol. 2017;17:679.

123. Hynes RO. The Extracellular Matrix: Not Just Pretty Fibrils. Science. 2009:326(5957):1216-9.

124. Hallmann R, Zhang X, Di Russo J, Li L, Song J, Hannocks MJ, Sorokin L. The regulation of immune cell trafficking by the extracellular matrix. Curr Opin Cell Biol. 2015;36:54-61.

125. Friedl P, Wolf K. Proteolytic and non-proteolytic migration of tumour cells and leucocytes. Biochem. Soc. Symp. 2003;70:277-85.

126. Lämmermann T, Bader BL, Monkley SJ, Worbs T, Wedlich-Söldner R, Hirsch K, Keller M, Förster R, Critchley DR, Fässler R, et al. Rapid leukocyte migration by integrin-independent flowing and squeezing. Nature. 2008;453:51

127. Wolf $K$, te Lindert $M$, Krause M, Alexander $S$, te Riet J, Willis AL, Hoffman RM Figdor CG, Weiss SJ, Friedl P. Physical limits of cell migration: Control by ECM space and nuclear deformation and tuning by proteolysis and traction force. J. Cell Biol. 2013;201(7):1069-84.

128. Salmon $H$, Franciszkiewicz K, Damotte D, Dieu-Nosjean MC, Validire $P$, Trautmann A, Mami-Chouaib F, Donnadieu E. Matrix architecture defines the preferential localization and migration of T cells into the stroma of human lung tumors. Eur. J. Clin. Investig. 2012;122(3):899-910.

129. Evanko SP, Potter-Perigo S, Bollyky PL, Nepom GT, Wight TN. Hyaluronan and versican in the control of human T-lymphocyte adhesion and migration Matrix Biol. 2012;31(2):90-100

130. Abramsson A, Lindblom P, Betsholtz C. Endothelial and nonendothelial sources of PDGF-B regulate pericyte recruitment and influence vascular pattern formation in tumors. J. Clin. Invest. 2003:112(8):1142-51.

131. Mueller MM, Fusenig NE. Friends or foes - bipolar effects of the tumour stroma in cancer. Nat Rev Cancer. 2004;4(11):839-49.

132. Bose A, Barik S, Banerjee S, Ghosh T, Mallick A, Bhattacharyya Majumdar S, Goswami KK, Bhuniya A, Banerjee S, Baral R, et al. Tumor-derived vascular pericytes anergize Th cells. J. Immunol. 2013;191(2):971-81.

133. Zhao W, Zhang L, Xu Y, Zhang Z, Ren G, Tang K, Kuang P, Zhao B, Yin Z, Wang $X$. Hepatic stellate cells promote tumor progression by enhancement of immunosuppressive cells in an orthotopic liver tumor mouse model. Lab Invest. 2014;94(2):182-91.

134. Ochs K, Sahm F, Opitz CA, Lanz TV, Oezen I, Couraud PO, von Deimling A, Wick W, Platten M. Immature mesenchymal stem cell-like pericytes as mediators of immunosuppression in human malignant glioma. J. Neuroimmunol. 2013;265(1-2):106-16.

135. Maciag PC, Seavey MM, Pan ZK, Ferrone S, Paterson Y. Cancer immunotherapy targeting the high molecular weight melanoma-associated antigen protein results in a broad antitumor response and reduction of pericytes in the tumor vasculature. Cancer Res. 2008:68(19):8066-75.

136. Kalluri R, Zeisberg M. Fibroblasts in cancer. Nat. Rev. Cancer. 2006;6(5):392-401.

137. Chen L, Qiu X, Wang X, He J. FAP positive fibroblasts induce immune checkpoint blockade resistance in colorectal cancer via promoting immunosuppression. Biochem. Biophys. Res. Commun. 2017:487(1):8-14

138. Wen X, He X, Jiao F, Wang C, Sun Y, Ren X, Li Q. Fibroblast Activation Protein-alpha-Positive Fibroblasts Promote Gastric Cancer Progression and Resistance to Immune Checkpoint Blockade. Oncol. Res. 2017;25(4):629-40. 
139. Ozdemir BC, Pentcheva-Hoang T, Carstens JL, Zheng X, Wu CC, Simpson TR, Laklai H, Sugimoto H, Kahlert C, Novitskiy SV, et al. Depletion of carcinomaassociated fibroblasts and fibrosis induces immunosuppression and accelerates pancreas cancer with reduced survival. Cancer cell. 2014;25(6):719-34.

140. Rhim AD, Oberstein PE, Thomas DH, Mirek ET, Palermo CF, Sastra SA, Dekleva EN, Saunders T, Becerra CP, Tattersall IW, et al. Stromal elements act to restrain, rather than support, pancreatic ductal adenocarcinoma. Cancer cell. 2014;25(6):735-47.

141. Ahamed J, Burg N, Yoshinaga K, Janczak CA, Rifkin DB, Coller BS. In vitro and in vivo evidence for shear-induced activation of latent transforming growth factor-beta1. Blood. 2008;112(9):3650-60.

142. Travis MA, Sheppard D. TGF-beta activation and function in immunity. Annual review of immunology. 2014;32:51-82.

143. Li MO, Flavell RA. TGF- $\beta$ : A Master of All T Cell Trades. Cell. 2008;134(3):392-404

144. Xu J, Lamouille S, Derynck R. TGF-beta-induced epithelial to mesenchymal transition. Cell research. 2009;19(2):156-72.

145. Hynes RO, Naba A. Overview of the matrisome-an inventory of extracellular matrix constituents and functions. Cold Spring Harb. Perspect. Biol. 2012;4(1):a004903.

146. Naba A, Clauser KR, Hoersch S, Liu H, Carr SA, Hynes RO. The matrisome: in silico definition and in vivo characterization by proteomics of normal and tumor extracellular matrices. Mol. Cell. Proteomics. 2012;11(4):M111.014647.

147. Nebuloni M, Albarello L, Andolfo A, Magagnotti C, Genovese L, Locatelli I, Tonon G, Longhi E, Zerbi P, Allevi R, et al. Insight On Colorectal Carcinoma Infiltration by Studying Perilesional Extracellular Matrix. Sci Rep. 2016;6:22522.

148. Rygiel TP, Stolte EH, de Ruiter T, van de Weijer ML, Meyaard L. Tumorexpressed collagens can modulate immune cell function through the inhibitory collagen receptor LAIR-1. Mol. Immunol. 2011;49(1):402-6.

149. Simon T, Bromberg JS. Regulation of the Immune System by Laminins. Trends Immunol. 38(11):858-71.

150. Warren KJ, Iwami D, Harris DG, Bromberg JS, Burrell BE. Laminins affect T cell trafficking and allograft fate. J. Clin. Invest. 2014;124(5):2204-18.

151. Song J, Zhang X, Buscher K, Wang Y, Wang H, Di Russo J, Li L, Lütke-Enking S, Zarbock A, Stadtmann A, et al. Endothelial Basement Membrane Laminin 511 Contributes to Endothelial Junctional Tightness and Thereby Inhibits Leukocyte Transmigration. Cell reports. 2017;18(5):1256-69.

152. Kaoru M. Laminin-5 (laminin-332): Unique biological activity and role in tumor growth and invasion. Cancer Science. 2006;97(2):91-8.

153. Pouliot N, Kusuma N. Laminin-511: a multi-functional adhesion protein regulating cell migration, tumor invasion and metastasis. Cell Adhes. Migr. 2013;7(1):142-9.

154. Kaplan RN, Riba RD, Zacharoulis S, Bramley AH, Vincent L, Costa C, MacDonald DD, Jin DK, Shido K, Kerns SA, et al. VEGFR1-positive haematopoietic bone marrow progenitors initiate the pre-metastatic niche. Nature. 2005;438(7069):820-7.

155. Afratis N, Gialeli C, Nikitovic D, Tsegenidis T, Karousou E, Theocharis AD, Pavão MS, Tzanakakis GN, Karamanos NK. Glycosaminoglycans: key players in cancer cell biology and treatment. FEBS Journal. 2012;279(7):1177-97.

156. Chanmee T, Ontong P, Itano N. Hyaluronan: A modulator of the tumor microenvironment. Cancer Letters. 375(1):20-30.

157. Jacobetz MA, Chan DS, Neesse A, Bapiro TE, Cook N, Frese KK, Feig C, Nakagawa T, Caldwell ME, Zecchini HI, et al. Hyaluronan impairs vascular function and drug delivery in a mouse model of pancreatic cancer. Gut. 2013;62(1):112-20.

158. Alaniz L, Rizzo M, Malvicini M, Jaunarena J, Avella D, Atorrasagasti C, Aquino JB, Garcia M, Matar P, Silva M, et al. Low molecular weight hyaluronan inhibits colorectal carcinoma growth by decreasing tumor cell proliferation and stimulating immune response. Cancer Letters. 2009;278(1):9-16.

159. Maharjan AS, Pilling D, Gomer RH. High and Low Molecular Weight Hyaluronic Acid Differentially Regulate Human Fibrocyte Differentiation. PloS one. 2011;6(10):e26078.

160. Nikitovic D, Tzardi M, Berdiaki A, Tsatsakis A, Tzanakakis GN. Cancer Microenvironment and Inflammation: Role of Hyaluronan. Front. Immunol. 2015;6:169.

161. Bollyky PL, Falk BA, Wu RP, Buckner JH, Wight TN, Nepom GT. Intact extracellular matrix and the maintenance of immune tolerance: high molecular weight hyaluronan promotes persistence of induced CD4+CD25+ regulatory T cells. J. Leukoc. Biol. 2009;86(3):567-72.

162. Blackhall FH, Merry CLR, Davies EJ, Jayson GC. Heparan sulfate proteoglycans and cancer. Br J Cancer. 2001;85(8):1094-8.
163. Soares MA, Teixeira FCOB, Fontes M, Ar, \#xea, as AL, \#xfa, cia, Leal MG, Pav et al: Heparan Sulfate Proteoglycans May Promote or Inhibit Cancer Progression by Interacting with Integrins and Affecting Cell Migration. Biomed. Res. Int. 2015, 2015:8.

164. Sarrazin S, Lamanna WC, Esko JD. Heparan Sulfate Proteoglycans. Cold Spring Harb. Perspect. Biol. 2011;3(7):a004952.

165. Caruana I, Savoldo B, Hoyos V, Weber G, Liu H, Kim ES, Ittmann MM, Marchetti D, Dotti G. Heparanase promotes tumor infiltration and antitumor activity of CAR-redirected T lymphocytes. Nat. Med. 2015;21(5):524-9.

166. Merline R, Schaefer RM, Schaefer L. The matricellular functions of small leucine-rich proteoglycans (SLRPs). J Cell Commun Signal. 2009;3(3):323-35.

167. Wight TN, Kang I, Merrilees MJ. Versican and the Control of Inflammation. Matrix Biol. 2014;35:152-61.

168. Du WW, Yang W, Yee AJ. Roles of versican in cancer biology-tumorigenesis, progression and metastasis. Histol. Histopathol. 2013;28(6):701-13.

169. Ricciardelli C, Sakko AJ, Ween MP, Russell DL, Horsfall DJ. The biological role and regulation of versican levels in cancer. Cancer Metastasis Rev. 2009;28(1-2):233-45

170. Said N, Sanchez-Carbayo M, Smith SC, Theodorescu D. RhoGDI2 suppresses lung metastasis in mice by reducing tumor versican expression and macrophage infiltration. J. Clin. Invest. 2012;122(4):1503-18.

171. Wight TN. Versican - a versatile extracellular matrix proteoglycan in cell biology. Curr Opin Cell Biol. 2002;14:617-23.

172. Wight TN, Kinsella MG, Evanko SP, Potter-Perigo S, Merrilees MJ. Versican and the regulation of cell phenotype in disease. Biochim. Biophys. Acta. 2014;1840(8):2441-51.

173. Zhang Z, Miao L, Wang L. Inflammation Amplification by Versican: The First Mediator. Int. J. Mol. Sci. 2012;13(6)

174. Kim S, Takahashi H, Lin WW, Descargues P, Grivennikov S, Kim Y, Luo JL, Karin M. Carcinoma-produced factors activate myeloid cells through TLR2 to stimulate metastasis. Nature. 2009;457(7225):102-6.

175. Kim S, Karin M. Role of TLR2-dependent inflammation in metastatic progression. Ann. N. Y. Acad. Sci. 2011;1217(1):191-206

176. Tang M, Diao J, Gu H, Khatri I, Zhao J, Cattral MS. Toll-like Receptor 2 Activation Promotes Tumor Dendritic Cell Dysfunction by Regulating IL-6 and IL-10 Receptor Signaling. Cell reports. 2015;13(12):2851-64.

177. Gao D, Joshi N, Choi H, Ryu S, Hahn M, Catena R, Sadik H, Argani P, Wagner $\mathrm{P}$, Vahdat LT, et al. Myeloid progenitor cells in the premetastatic lung promote metastases by inducing mesenchymal to epithelial transition. Cancer Res. 2012:72(6):1384-94.

178. Gorter A, Zijlmans HJ, van Gent H, Trimbos JB, Fleuren GJ, Jordanova ES. Versican expression is associated with tumor-infiltrating CD8positive T cells and infiltration depth in cervical cancer. Mod. Pathol. 2010;23(12):1605-15

179. Koyama H, Hibi T, Isogai Z, Yoneda M, Fujimori M, Amano J, Kawakubo M, Kannagi R, Kimata K, Si T, et al. Hyperproduction of Hyaluronan in NeuInduced Mammary Tumor Accelerates Angiogenesis through Stromal Cell Recruitment : Possible Involvement of Versican/PG-M. Am. J. Pathol. 2007; 170(3):1086-99.

180. Shen XH, Lin WR, Xu MD, Qi P, Dong L, Zhang QY, Ni SJ, Weng WW, Tan C, Huang $D$, et al. Prognostic significance of Versican expression in gastric adenocarcinoma. Oncogenesis. 2015;4:e178.

181. Kelwick R, Desanlis I, Wheeler GN, Edwards DR. The ADAMTS (A Disintegrin and Metalloproteinase with Thrombospondin motifs) family. Genome Biology. 2015;16(1):113.

182. Toupance S, Brassart B, Rabenoelina F, Ghoneim C, Vallar L, Polette M, Debelle $L$, Birembaut $P$. Elastin-derived peptides increase invasive capacities of lung cancer cells by post-transcriptional regulation of MMP-2 and UPA. Clin. Exp. Metastasis. 2012;29(5):511-22.

183. Thomas AH, Edelman ER, Stultz CM. Collagen fragments modulate innate immunity. Exp. Biol. Med. 2007;232(3):406-11.

184. Horejs C-M, Serio A, Purvis A, Gormley AJ, Bertazzo S, Poliniewicz A, Wang AJ, DiMaggio P, Hohenester E, Stevens MM. Biologically-active laminin-111 fragment that modulates the epithelial-to-mesenchymal transition in embryonic stem cells. Proc. Natl. Acad. Sci. U. S. A. 2014;111(16):5908-13.

185. Hope C, Foulcer S, Jagodinsky J, Chen SX, Jensen JL, Patel S, Leith C, Maroulakou I, Callander N, Miyamoto S, et al. Immunoregulatory roles of versican proteolysis in the myeloma microenvironment. Blood. 2016;128(5):680-5.

186. Hope C, Emmerich PB, Papadas A, Pagenkopf A, Matkowskyj KA, Van De Hey DR, Payne SN, Clipson L, Callander NS, Hematti P, et al. Versican-Derived 
Matrikines Regulate Batf3-Dendritic Cell Differentiation and Promote T Cell Infiltration in Colorectal Cancer. J. Immunol. 2017;199(5):1933-41.

187. Shay G, Lynch CC, Fingleton B. Moving targets: Emerging roles for MMPs in cancer progression and metastasis. Matrix Biology. 2015;4446(Supplement C):200-6.

188. Godefroy E, Gallois A, Idoyaga J, Merad M, Tung N, Monu N, Saenger Y, Fu $Y$, Ravindran R, Pulendran B, et al. Activation of toll-like receptor-2 by endogenous matrix metalloproteinase-2 modulates dendritic-cell-mediated inflammatory responses. Cell reports. 2014;9(5):1856-70.

189. Pavlaki M, Zucker S. Matrix metalloproteinase inhibitors (MMPIs): The beginning of phase I or the termination of phase III clinical trials. Cancer Metastasis Rev. 2003;22(2):177-203

190. Cathcart J, Pulkoski-Gross A, Cao J. Targeting matrix metalloproteinases in cancer: Bringing new life to old ideas. Genes \& Diseases. 2015;2(1):26-34.

191. Cal S, Lopez-Otin C. ADAMTS proteases and cancer. Matrix Biol. 2015:44-46:77-85.

192. Liu Y, Yasukawa M, Chen K, Hu L, Broaddus RR, Ding L, Mardis ER, Spellman $P$, Levine DA, Mills GB, et al. Association of Somatic Mutations of ADAMTS Genes With Chemotherapy Sensitivity and Survival in High-Grade Serous Ovarian Carcinoma. JAMA Oncol. 2015;1(4):486-94.

193. Huang Y, Zhang SD, McCrudden C, Chan KW, Lin Y, Kwok HF. The prognostic significance of PD-L1 in bladder cancer. Oncol. Rep. 2015;33(6):3075-84.

194. Brew K, Nagase $\mathrm{H}$. The tissue inhibitors of metalloproteinases (TIMPs): an ancient family with structural and functional diversity. Biochim Biophys Acta. 2010;1803(1):55-71.

195. Jackson HW, Defamie V, Waterhouse P, Khokha R. TIMPs: versatile extracellular regulators in cancer. Nat Rev Cancer. 2017:17(1):38-53.

196. Yan C, Boyd DD. Regulation of matrix metalloproteinase gene expression. J. Cell. Physiol. 2007;211(1):19-26.

197. Chen Daniel S, Mellman I. Oncology Meets Immunology: The CancerImmunity Cycle. Immunity. 2013;39(1):1-10.

Ready to submit your research? Choose BMC and benefit from:

- fast, convenient online submission

- thorough peer review by experienced researchers in your field

- rapid publication on acceptance

- support for research data, including large and complex data types

- gold Open Access which fosters wider collaboration and increased citations

- maximum visibility for your research: over $100 \mathrm{M}$ website views per year

At BMC, research is always in progress.

Learn more biomedcentral.com/submissions 